\title{
EFFECT OF IRRADIATION AND HEAT TREATMENTS ON ANTIOXIDANT ACTIVITY AND MICROBIAL LOAD IN CURCUMA (curcuma longa)
}

\author{
GADO BAKR AHMED GADO
}

Food Tec. Res. Inst., ARC, Giza, Ministry of Agric. Cairo, Egypt.

(Manuscript received 12 September 2017)

\begin{abstract}
$\mathrm{T}$ urmeric is the common name used for the dried rhizome of Curcuma longa L. It is a rich source for natural colorants and useful phytochemicals compounds, so that it is used as a spice and herbal in food processing especially in ready food but it's highly contaminated with pathogenic. Therefore, to find the suitable applied methods for preventing contamination with pathogenic microorganisms without affecting quality. The present work introduced comprehensive studies by using different ordinary treatments as thermal treatments. The investigated treatments included control, thermal treatments at $50^{\circ} \mathrm{C}$ for 15 and $30 \mathrm{~min}$. and the irradiation process doses with 5.0 and $10.0 \mathrm{kGy}$. The treated samples were evaluated with respect to microbiological and chemical analysis. The obtained results proved that the best ability and suitable method is the gamma irradiation at 10.0 kGy process than other treatments due to its reduce the microbial contamination through activation the antibacterial activity against selected pathogenic microbes such as Staphylococcus aureus, Klebsiella pneumonia, E. coli and Bacillus subtilus. In addition, the same dose was increased the efficiency of antioxidant activity (49\%) than other treatments. It was also; found that there was no change in colorant but the fractionation and identification of phenolic and flavonoids compounds by HPLC analysis proved presence of 56 compounds of phenolic and flavonoids which were affected by tested treatments. Irradiation doses were more affecting to generate new major compounds from minor phenols or flavonoids. The advantages of last compounds were increased the antioxidant activity besides increased the antibacterial activity against tested pathogenic microbes.
\end{abstract}

Key words: Turmeric, curcumin, irradiation, antibacterial.

\section{INTRODUCTION}

Turmeric rhizome (Curcuma longa L.) is the underground rhizome of Curcuma long. It is used as a spice, natural colorant and herbal medicine. India is the major producer and exporter of turmeric. Turmeric rhizomes contained a heavily microbe load due to being grown under soil surface besides role of environmental factors such as temperature, humidity, pre/ post-harvesting conditions, and the storage condition (Araújo and Bauab, 2012). High levels of pathogenic microbes were recorded in food 
stuffs mainly as being 'ready-to-use'. Whereas, no additional further food processing which can cause out break as recorded before in USA, due to pathogenic bacteria. Some outbreaks of salmonellosis have been linked to the consumption of foods seasoned with spices involved turmeric powder. Bacillus cereus may also be present in spices and herbs, usually at counts below $10^{3} \mathrm{CFU} / \mathrm{g}$ but may multiply to high levels $\left(10^{5}-10^{6} \mathrm{CFU} / \mathrm{g}\right)$ in food to which it is added; this may be sufficient to cause food poisoning if the food is inappropriately handled or stored (D'Aoust, 1994).

In addition, the importance of correct food handling practices and usage of herbs and spices by end users cannot be overemphasized. (Little et al., 2003).

Fumigation with chemicals as ethylene and propylene oxide are being progressively banned in several countries because of their toxic, mutagenic and carcinogenic effects (Fowles et al., 2001). While, Lee et al.,( 2005) showed that Yirradiation appeared to be the best way for microbial decontamination of spices and herbs without causing alterations in the condiment quality. The utilization of $\mathrm{y}^{-}$ irradiation for microbial decontamination of whole spices and spice powders is legally allowed in more than 50 countries worldwide and it is well established that 40 countries are using this technology commercially (Farag et al., 2013).

The active constituents are the flavonoid curcumin (diferuloylmethane) and other various volatile oils, including tumerone, atlantone, and zingiberene. Components of turmeric especially curcumin has been shown to have antiinflammatory, antiviral, and anticancer properties (Ji et al.,2012). The literature review confirmed plethora of information available on safety aspects of curcumin and essential oil fractions of turmeric (Liju et al., 2012).

While curcuminoids based extracts were well studied for their pharmacological and safety aspects, polysaccharide extract of turmeric is gaining importance since it showed to have various pharmacological activities, which include antidiabetic, antitumour, antidepressant, antioxidant, antimicrobial, antifertility, hepatoprotective, and immunomodulatory properties (Mohankumar and Farlane,2011). Therefore, the present work introduced an evaluation on turmeric treated with two methods (thermal and $\mathrm{\gamma}$-irradiation) for decontamination, the microbiological, biochemical characteristic by HPLC profile, antioxidant activity, and coloring ( UV-visible scanning) materials .

\section{MATERIALS AND METHODS}

\section{Materials}

Turmeric Powder (Curcuma longa L.) rhizomes samples were collected in sterilized glass bottles from local markets in Cairo, Egypt.Candida albicans (CA), 
Aspergillus niger (AN), as well as four bacteria species, namely, Gram positive bacteria, Staphylococcus aureus (SA), and Bacillus subtilus (BS), Gram negative bacteria , Klebsiella pneumoniae (KP), and Escherichia coli (EC) were obtained from the Egyptian Microbial Culture Collection, (EMCC), Cairo Microbiological Resources Center (Cairo MIRCEN), Faculty of Agriculture, Ain Shams University, Egypt. Chloramphenicol,Trimethoprim/ sulphamethnd oxazole, adimethyl sulfoxide (DMSO) solvent were purchased from Sigma (St. Louis, MO,USA). Sabouraud dextrose agar and trypticase soya agar medium were purchased from Oxoid Laboratories, UK.

\section{Thermal and Irradiation of samples}

The collected turmeric powders (as one replicate $=250 \mathrm{~g}$.) were thermally treated at $50^{\circ} \mathrm{C}$ for 15 and $30 \mathrm{~min}$. Meanwhile, Irradiation treatment were carried out at doses of 5.0 and $10.0 \mathrm{kGy}$ using a ${ }^{60} \mathrm{Co}$ Russian gamma chamber, (dose rate 1.3 kGy/h), belonging to Cyclotron Project, Nuclear Research Center, Atomic Energy Authority, Cairo, Egypt.

\section{Microbiological analysis}

Total bacterial counts (CFU/g) were determined according to Farag et al. (2013). Total fungi counts (CFU/g) were conducted according to the method of Ichinoe Zirnstein and Rehberger. (1983).

\section{Antimicrobial activity of turmeric alcohol extract}

In -vitro antimicrobial screening of turmeric alcohol extract was prepared according to Pundir and Jain (2010). Antimicrobial activity was carried out using the agar disc diffusion method; culture of strains Candida albicans and Aspergillus niger were sub-cultured on Sabouraud dextrose agar, as well as four bacteria species, Gram positive bacteria, namely, Staphylococcus aureus (strains), and Bacillus subtilus, Gram negative bacteria , Klebsiella pneumoniae, and Escherichia coli were sub-cultured on Trypticase soya agar medium. Chloramphenicol and Trimethoprim/ sulphamethoxazole antibacterial agent were used as references to evaluate the potency of the tested compounds under the same conditions. (Hossain et al., 2012).

\section{Chemical analysis}

Total phenol content (TPC) was determined as described by Swain and Hillis (1959) and later modified by Singleton and Rossi (1965). Antioxidant Activity was investigated with 2, 2'-Diphenyl-1-picrylhydrazyl method (DPPH) as described by Miller et al., (2000). Color changes of irradiation or thermal treatments were determined with spectrophotometric analysis in (1\%) Turmeric aqueous solution before and after treated samples. The mixtures were centrifuged at $10 \mathrm{~g}$ for $15 \mathrm{~min}$, and the clear 
solutions were scanned by UV-Visible absorbance measurements at different wavelength of maximal absorption. A UV/visible spectrophotometer unicam 8625 (Japan) was used. A calibration plot constructed with diluted solutions of tested sample was employed. The degree of color degradation was calculated as $(c b-c a) x$ 100/cb, where cb are untreated sample, ca after treated (Farag et al., 2013).

\section{HPLC analysis of phenolic and flavonoid Compounds.}

The polyphenol components of turmeric were determined by HPLC according to the method described by Goupy et al., (1999). (1-3 ml) sample after preparation was collected from the previous step in a vial for injection into HPLC Hewllet packared (series 1050) equipped with auto-sampling injector, solvent degasser, ultraviolet (UV) detector was set at $280 \mathrm{~nm}$ and quarter HP pump (series 1050). Retention time and peak area (\%) were used to identify and calculate the phenolic compound concentrations by standard curve of specified concentration. The same instrument was used, also, to determine the flavonoids compounds of Turmeric. After sample preparation (1-3 $\mathrm{ml}$ ) was collected from the previous was step in a vial for injection into a HPLC Hewllet Packared (series 1050) equipped with auto-sampling injector, solvent degasser, ultraviolet (UV) detector set at $330 \mathrm{~nm}$ and quarter HP pump (series 1050). The column temperature was maintained at $35^{\circ} \mathrm{C}$. Retention time and peak area (\%) were used to identify and calculate the flavonoids concentrations by standard curve of specified concentration.

\section{RESULTS AND DISCUSSION}

There is a growing interest in the development and evaluation of natural antioxidants from medicinal plant materials in the food industry and the field of preventive health care. Therefore, the hygienic view was applied to find the appreciate method for decontamination without affecting the quality of spices.

\section{Effects of the thermal and irradiation treatments on microbial load of turmeric}

Bacteria of public health importance, such as pathogenic, may be present and could potentially create a public health risk depending on the end use, such as addition to ready-to-eat foods that undergo no further processing. Some outbreaks of Salmonellosis have been linked to the consumption of turmeric powder (Little et al., 2003). The obtained results in Table (1) proved the presence of bacteria and fungi was in high levels in control samples. Natural levels of bacteria near $90 \times 10^{6}$ and $8 \times 10^{5}$ for fungi are logic due to many observations confirmed that the turmeric are microorganisms highly contaminated herbs. Its bacterial level reaches to 80 to 100 million per gram level (Farkas, 1988). It showed that $96 \%$ of tested turmeric samples 
have aerobic plate count more than $10^{5} / \mathrm{g}$. This due to its growth under soil surface besides role of environmental factors such as temperature, humidity, pre-/postharvesting conditions and the storage condition (Araújo and Bauab, 2012; Parveen et al., 2014). Whereas, investigated treatments were reduced these levels mainly $Y^{-}$ irradiation, i.e., irradiation at low dose (5.0 kGy) was reduced $3 \log$ from $6 \log$ of bacteria and 2 Log from 5 Log. of fungi at untreated samples. It was found that the high dose (10.0 kGy) was more effective. Whereas the thermal treatments either at long or short time at $50{ }^{\circ} \mathrm{C}$ was less effective in efficiency than irradiation for decontamination of turmeric. These results are in parallel with those obtained by some workers (Zaied et al.,1996; Lee, 2004) who reported that irradiation dose of 3.0 kGy without heat treatment reduced the microbial load in coriander, cumin, turmeric and chili from $6 \log$ to $3 \log$ and from $5 \log$ to $2 \log$ units depending on the storage temperature.

Table 1. Effect of thermal and irradiation treatments on microbial load of tested turmeric

\begin{tabular}{|l|l|l|}
\hline Treatments & Total bacterial count (CFU/g) & Total Fungi count (CFU/g) \\
\hline Control & $90 \times 10^{6}$ & $8 \times 10^{5}$ \\
\hline Thermal process $\left(50^{\circ} \mathrm{C}\right)$ & & \\
- Time 15 min. & $80 \times 10^{4}$ & $8.0 \times 10^{4}$ \\
- Time 30 min. & $20 \times 10^{4}$ & $6.0 \times 10^{4}$ \\
\hline Gamma irradiation & & \\
$-5.0 \mathrm{kGy}$. & $30 \times 10^{3}$ & $3.0 \times 10^{3}$ \\
$-10.0 \mathrm{kGy}$ & $20 \times 10^{2}$ & $4.0 \times 10$ \\
\hline
\end{tabular}

\section{Effect of heat and irradiation treatments on antimicrobial activity of turmeric}

In the present work ethyl extract was chosen rather than other solvents due to its potential as showed by many workers (Pundir and Jain 2010). The obtained results of antimicrobial activity (AA) of tested turmeric alcohol extracts against yeast, fungi, and bacterial species are investigated by disc-diffusion assay in Table (2). It is shows that AA of ethanol extracts of treated turmeric produced inhibition zones against Staphylococcus aureus, Klebsiella pneumonia, E.coli and Bacillus. Whereas, no effect was recorded against fungi or yeast from turmeric extract either treated or not. 
Table 2. Antimicrobial activity of treated turmeric ethyl extracts as inhibition diameter zones size $(\mathrm{mm})$

\begin{tabular}{|c|c|c|c|c|c|c|c|c|}
\hline \multirow{3}{*}{ Strains } & \multicolumn{8}{|c|}{ Treatments } \\
\hline & \multirow[t]{2}{*}{ Control } & \multicolumn{2}{|c|}{$\begin{array}{c}\text { Thermal process } \\
\left(50^{\circ} \mathrm{C}\right)\end{array}$} & \multicolumn{2}{|c|}{$\begin{array}{l}\text { Gamma } \\
\text { irradiation }\end{array}$} & \multicolumn{3}{|c|}{ Positive control } \\
\hline & & $15 \mathrm{~min}$ & $30 \mathrm{~min}$ & $\begin{array}{l}5.0 \\
\mathrm{kGy}\end{array}$ & $\begin{array}{l}10.0 \\
\text { kGy }\end{array}$ & Chloramphenicol & $\begin{array}{l}\mathrm{T} / \\
\mathrm{S}\end{array}$ & DMSO \\
\hline \multicolumn{9}{|c|}{ Yeast } \\
\hline C. albicans & N.R & N.R & N.R & N.R & N.R & 29 & 24 & N.R \\
\hline \multicolumn{9}{|c|}{ Fungi } \\
\hline A. niger & N.R & N.R & N.R & N.R & N.R & 20 & 18 & N.R \\
\hline \multicolumn{9}{|c|}{$\operatorname{Gram}(+)$} \\
\hline $\begin{array}{l}\text { Staph. } \\
\text { aureus }\end{array}$ & 11 & 15 & 17 & 17 & 24 & 25 & 13 & N.R \\
\hline B. subtilus & 9 & 10 & 11 & 15 & 25 & 30 & 10 & N.R \\
\hline \multicolumn{9}{|c|}{ Gram(-)13 } \\
\hline $\begin{array}{l}\text { K. } \\
\text { pneumonia }\end{array}$ & 9 & 19 & 16 & 12 & 26 & 24 & 23 & $N . R$ \\
\hline E. coli & 10 & 10 & 11 & 13 & 25 & 24 & 12 & N.R \\
\hline
\end{tabular}

N.R= no response T/ S: Trimethoprim/ sulphamethoxazole DMSO: Dimethyl sulfoxide

Antimicrobial activity of the untreated turmeric extract was observed by (Niamsa and Sittiwet ,2009). The explanation of antimicrobial activity enhancement after thermal or irradiation process due to high content of phenolic and flavonoid which resulted after processing. This phenomenon in food after different process was observed by workers (Horváthová, 2007; Naguib et al., 2012; Farag et al., 2014).

\section{Effect of thermal and irradiation treatments on total phenols contents and antioxidant activity of turmeric.}

Data in Table (3) and Fig.(1) show that, there are slight change in total phenols contents in all treatments. Meanwhile, the antioxidant activity increased in both thermal and Gamma irradiation treatments compared to control sample. The high percent of increase in antioxidant activity was observed after using high dose of Gamma irradiation ( $10.0 \mathrm{kGy}$ ) was $49 \%$ but less value was resulted in the low dose of Gamma irradiation (5.0 kGy) was $20 \%$. A little increase was also, resulted by thermal treatments. Same results was obtained by (Zaied et al., 1996 ).

Table 3. Effect of thermal and irradiation treatments on total phenols contents and antioxidant activity of turmeric.

\begin{tabular}{|l|l|l|l|}
\hline Treatments & $\begin{array}{l}\text { Total phenols } \\
(\mathrm{mg} / \mathrm{g})\end{array}$ & $\begin{array}{l}\text { Antioxidant activity } \\
\%\end{array}$ & $\begin{array}{l}\text { Increasing } \\
\% *\end{array}$ \\
\hline Control & 11.12 & 29.72 & \\
\hline Thermal process $\left(50^{\circ} \mathrm{C}\right)$ & & & 23 \\
-Time $15 \mathrm{~min}$. & 10.70 & 36.48 & 34 \\
-Time $30 \mathrm{~min}$ & 10.65 & 39.72 & 20 \\
\hline Gamma irradiation & & & 49 \\
-5.0 kGy & 11.05 & 35.67 & \\
-10.0 kGy & 10.77 & 44.19 & \\
\hline
\end{tabular}

$* \mathrm{AA}$-increase $(\%)$ of $\mathrm{AA}=(\mathrm{AA}$ after treatment-AA before/AA before) $\mathrm{x} 100$ 


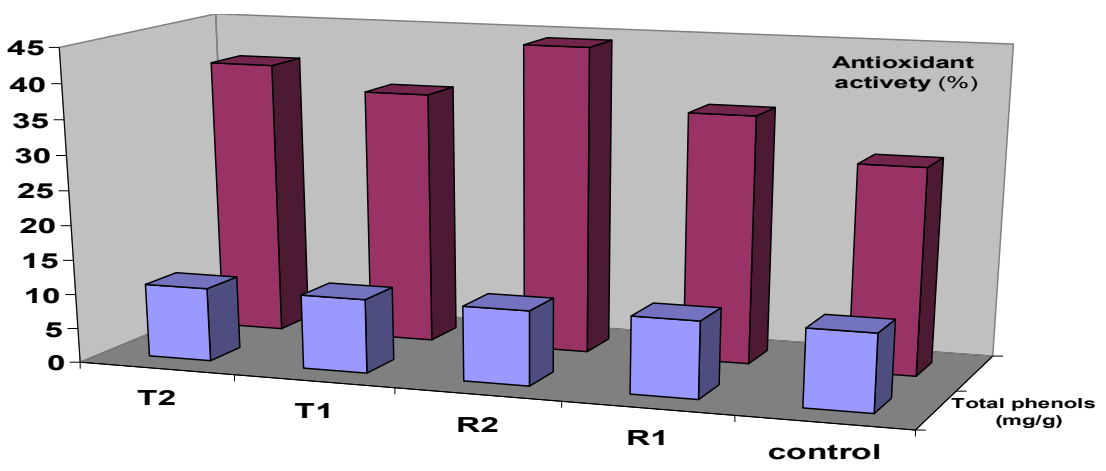

Fig. 1. Effect of thermal and irradiation treatments on total phenol contents and antioxidant activity of turmeric ( $\mathrm{T} 1$ and $\mathrm{T} 2=$ thermal treatments at $50^{\circ} \mathrm{C}$ for 15 and 30 min, respectively. R1 and R2= $y$-irradiation doses 5.0 and 10.0 KGy, respectively.

\section{UV-Visible scanning of treated turmeric extract}

For many centuries, turmeric has been used not only as a spice but also, as a natural colorant. The bright yellow powder of the ground rhizomes being one of the earliest known vegetable dyes. This yellow color results from the presence of a pigment called 'curcumin' which may be as high as 5-6\% (Akram et al., 2010). No wonder it is now known as the 'Yellow Wonder' The deep orange-yellow powder known as turmeric is prepared from boiled and dried rhizomes of the plant. Alcohol extracts scanning using UV-Scanning spectrophotometer, as shown in Fig. (2). Spectrum of all tested treated extracts. No higher changes were observed in the spectrum of extract of tested samples, except irradiated samples at its values were raised may be due to degradation of some compounds (Wang et al,. 2009 ).

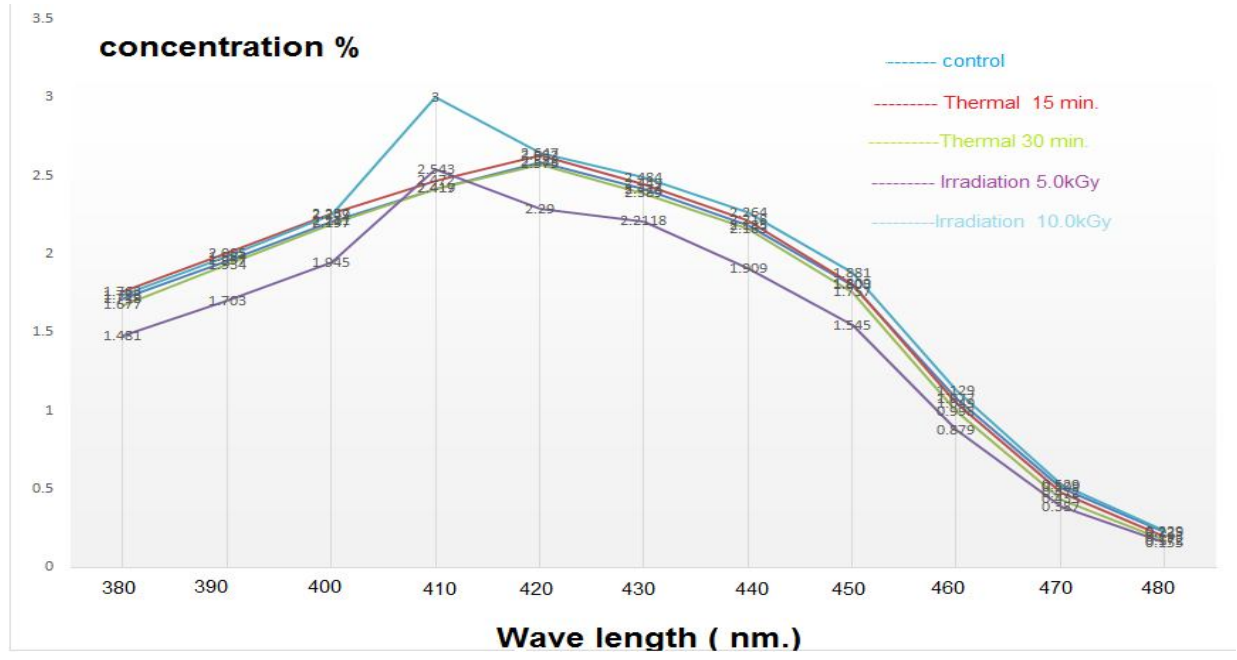

Fig. 2. UV-Visible scanning of treated turmeric extract 


\section{HPLC analysis of phenolic and flavonoids compounds of treated turmeric samples}

HPLC analysis of turmeric extract proved that of 56 compounds of phenolic, flavonoids were prevented and affected by tested treatments as shown in Table (3).Like same compounds obtained by Shiyou et al., (2011). The tabulated compounds involved, monoterpenes, sesquiterpenes, fatty acid, steroid besides different biochemical like volatile oils. The compounds can be classified to majore (with total area more than 5\%) and minor compounds less than 5\%. The major as isochroman ( $\mathrm{Rt}=4.89)$ and eucalyptol $(\mathrm{Rt}=8.015)$, but the minor present the big percent as shown in Fig. (3). Gamma irradiation doses only were more affecting on all these compounds, i.e. the major one as isochroman $(\mathrm{Rt}=4.89)$ in control samples which occupied (15.54\%) increased due to $y$-irradiation to $21.85 \%$ and $20.74 \%$ after irradiation with 5.0 and 10.0 kGy respectively, as shown in Table (3) and Fig.(3). Also, eucalyptol ( $\mathrm{Rt}=8.015)$ with $9.39 \%$ then decreased by all treatments, i.e. 5.93 and $0.59 \%$ for short and long time for thermal treatments. Whereas, irradiation was more destructive same compound to $0.3 \%, 0.93$ after irradiation with 5.0 and 10.0 kGy, respectively as shown in Table (3) and Fig.(3). Radio-degeneration lead to small molecular terpens, mono terpens as volatile oils which increased the total area of these minor compounds. The total of calculated (\%) identified phenols and flavonoids were increased by irradiation to 137 and $131 \%$ due to irradiation with 5.0, $10.0 \mathrm{kGy}$ respectively as shown in Table (3) and Fig. (3).The decomposition happen by irradiation or thermal treatments was usually observed by workers due to high energy which decompose some sensitive terminal groups as- $\mathrm{OH}$ then the major compound can produce series of low carbon number compounds less than $5 \%$ as shown in Fig.(3). The enhancement of phenols and flavonoids by different food processing especially by irradiation was observed by workers (Horváthová,2007, Naguib et al., 2012; Farag et al., 2014). 
Table 3. HPLC analysis of treated turmeric.

\begin{tabular}{|c|c|c|c|c|c|c|c|}
\hline \multirow[t]{2}{*}{ No. } & \multirow[t]{2}{*}{$\mathrm{Rt}$} & \multirow[t]{2}{*}{ Compound } & \multirow[t]{2}{*}{ Control } & \multicolumn{2}{|c|}{$\begin{array}{l}\text { Thermal treatment } \\
\text { (time, minute) }\end{array}$} & \multicolumn{2}{|c|}{$\begin{array}{l}\text { Irradiation } \\
\text { treatments } \\
(\mathrm{kGy})\end{array}$} \\
\hline & & & & 15 & 30 & 5.0 & 10.0 \\
\hline 1 & 4.98 & Isochroman & 15.37 & 15.54 & 16.94 & 21.85 & 20.74 \\
\hline 2 & 5.3 & Coumarin & 1.58 & 1.55 & 1.81 & 3.62 & 1.82 \\
\hline 3 & 5.7 & Cumic acid & 0.28 & 0.22 & 0.4 & 5.77 & 2.02 \\
\hline 4 & 6.16 & Methyl cumate & 0.25 & 0.47 & 0.25 & 1.7 & 1.23 \\
\hline 5 & 6.26 & 2,5-Dimethyl-para-anisaldehyde & 1.37 & 1.07 & 2.32 & 1.33 & 0.61 \\
\hline 6 & 6.61 & cis-Edulan & 0.28 & 0.45 & 0.3 & 0.51 & 0.8 \\
\hline 7 & 6.89 & Dimethoxydurene & 0.19 & 0.18 & 0.26 & 0.95 & 1.36 \\
\hline 8 & 7.055 & 3,5-Dimethoxycinnamic acid & 0.21 & 0.26 & 0.17 & 0.29 & 0.27 \\
\hline 9 & 7.2 & Esculetin & 1.51 & 0.71 & 0.67 & 0.3 & 0.38 \\
\hline 10 & 7.42 & Hexestrol & 0.37 & 0.19 & 0.23 & 0.36 & 1.14 \\
\hline 11 & 7.55 & $\beta$-Myrcene & 0.81 & 0.26 & 0.47 & 0.34 & 0.37 \\
\hline 12 & 7.7 & a-Phellandrene & 0.26 & 0.33 & 0.18 & 0.29 & 0.51 \\
\hline 13 & 7.9 & p-Cimene & 0.16 & 0.17 & 0.29 & 0.45 & 0.3 \\
\hline 14 & 8.015 & Eucalyptol & 9.39 & 5.93 & 0.59 & 0.29 & 0.93 \\
\hline 15 & 8.39 & Daidzein & 0.25 & 0.17 & 0.2 & 0.37 & 0.35 \\
\hline 16 & 8.65 & Terpinolene & 0.61 & 0.16 & 0.23 & 0.75 & 0.32 \\
\hline 17 & 9.12 & Sinapic acid & 0.61 & 0.6 & 0.84 & 0.32 & 0.54 \\
\hline 18 & 9.46 & Nabilone & 0.32 & 0.45 & 1.14 & 4.19 & 0.45 \\
\hline 19 & 9.7 & Fisetin & 0.21 & 0.21 & 0.24 & 2.36 & 5.46 \\
\hline 20 & 10.7 & $\begin{array}{l}\text { Chromone, 5-hydroxy-6,7,8-trimethoxy-2,3- } \\
\text { dimethyl- }\end{array}$ & 0.41 & 0.18 & 0.49 & 0.51 & 3.27 \\
\hline 21 & 11.38 & $\beta$ Ionol & 0.68 & 0.34 & 0.41 & 1.35 & 0.81 \\
\hline 22 & 11.78 & geranyl-a-terpinene & 0.22 & 0.56 & 0.22 & 0.29 & 2.21 \\
\hline 23 & 12.11 & a-Curcumene & 0.42 & 0.49 & 0.47 & 0.79 & 0.24 \\
\hline 24 & 12.3 & trans-Nuciferol & 2.97 & 2.83 & 3.49 & 0.57 & 0.26 \\
\hline 25 & 12.4 & a-Zingiberene & 1.95 & 2.06 & 2.28 & 1.32 & 1.04 \\
\hline 26 & 12.45 & a-Ylangene & 0.66 & 0.35 & 0.24 & 0.8 & 2.17 \\
\hline 27 & 12.566 & cis-Farnesol & 2 & 1.33 & 1.66 & 0.33 & 0.42 \\
\hline 28 & 12.685 & cis-Thujopsene & 0.28 & 0.42 & 0.29 & 28.01 & 23.08 \\
\hline 29 & 12.889 & (-)-Spathulenol & 0.39 & 0.75 & 0.37 & 0.6 & 0.81 \\
\hline 30 & 12.97 & 9-Methoxycalamenene & 0.21 & 0.3 & 0.19 & 4.33 & 5.56 \\
\hline 31 & 13.18 & Germacrene & 1.67 & 1.37 & 1.83 & 0.35 & 0.45 \\
\hline 32 & 13.28 & $\beta$-Himachalene & 0.2 & 0.46 & 0.25 & 1.25 & 1.34 \\
\hline 33 & 13.47 & $\delta$-Neoclovene & 0.7 & 0.39 & 0.73 & 0.51 & 1.07 \\
\hline 34 & 13.55 & Caryophylene oxide & 1.41 & 1.43 & 1.73 & 1.31 & 2.42 \\
\hline 35 & 13.62 & $\beta$-Gurjunene & 6.6 & 6.79 & 7.42 & 0.59 & 1.06 \\
\hline 36 & 13.69 & Palustrol & 3.05 & 3.63 & 5.51 & 0.96 & 0.81 \\
\hline 37 & 13.85 & $\beta$-Santalol & 1.48 & 1.56 & 2 & 0.67 & 0.77 \\
\hline 38 & 13.93 & $\mathrm{y}$-Elemene & 3.14 & 3.34 & 4.66 & 0.42 & 0.42 \\
\hline 39 & 14.17 & $\delta$-Tocopherol & 1.9 & 0.68 & 2.2 & 2.14 & 2.55 \\
\hline 40 & 14.24 & (S)-(-)-Citronellic acid & 1.39 & 0.67 & 1.48 & 0.28 & 0.43 \\
\hline 41 & 14.38 & Z)-trans- a-Bergamotol & 1.98 & 2.05 & 3.4 & 1.13 & 1.68 \\
\hline 42 & 14.44 & Squalene & 1.03 & 0.71 & 0.85 & 3.24 & 5.89 \\
\hline 43 & 14.56 & Sclareol & 2.37 & 1.79 & 2.16 & 1.53 & 1.2 \\
\hline 44 & 15.27 & p-Menth-1-en-3-one & 0.48 & 0.21 & 1.34 & 0.66 & 0.43 \\
\hline 45 & 15.42 & Camphoric acid & 1.24 & 0.28 & 1.57 & 21.85 & 20.74 \\
\hline 46 & 15.6 & Digitoxin & 1.08 & 1.38 & 1 & 3.62 & 1.82 \\
\hline 47 & 15.7 & Octadecanoic acid & 5.26 & 4.46 & 4.92 & 5.77 & 2.02 \\
\hline 48 & 15.8 & Zearalenone & 1.51 & 0.72 & 1.01 & 1.7 & 1.23 \\
\hline 49 & 16.86 & Linolenic acid & 4.18 & 4.46 & 4.26 & 1.33 & 0.61 \\
\hline 50 & 16.96 & Lupulon & 3.87 & 7.08 & 8.47 & 0.51 & 0.8 \\
\hline 51 & 17.1 & cis-Vaccenic acid & 1.65 & 2.2 & 1.68 & 0.95 & 1.36 \\
\hline 52 & 18.9 & D-Glucuronic acid & 2.01 & 1.51 & 0.95 & 0.29 & 0.27 \\
\hline 53 & 20.28 & 7,8-Dihydro-a-ionone & 1.91 & 0.54 & 1.19 & 0.3 & 0.38 \\
\hline 54 & 22.298 & methyl a-curacinoside & 0.87 & 0.36 & 0.48 & 0.36 & 1.14 \\
\hline 55 & 23.11 & Lutein & 1.92 & 0.92 & 0.42 & 0.34 & 0.37 \\
\hline 56 & 23.6 & Rhodovibrin & 2.89 & 12.47 & 0.84 & 0.29 & 0.51 \\
\hline
\end{tabular}




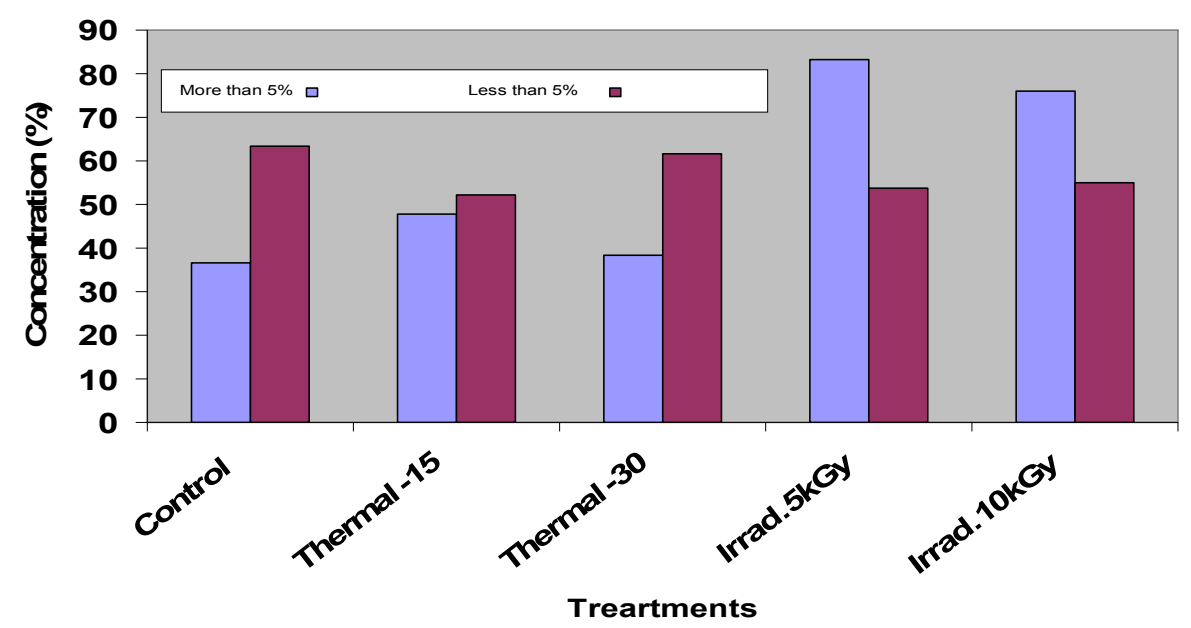

Fig. 3. Effect of treatments on phenols and flavonoids compounds (\%).

\section{CONCLUSION}

Finally, it could be clearly concluded through this study, this work that has technological and applicable values, as it proved the significance of turmeric as a natural colorant and also as a spice preferred by the majority of consumers. Besides, irritation was an effective procedure to increase the antioxidant activity substances of turmeric as well as inhibiting the activity of pathogenic bacteria. It was also proved that irradiation had no harmful effect on coloring capacity of turmeric.

\section{REFERENCES}

1. Akram, M.; Uddin, S. and Ahmed, A. 2010. Curcuma longa and curcumin: a review article. Romanian Journal of Biology, 55:65-70.

2. Araújo, M. G. F. and Bauab, T. M. 2012. Microbial quality of medicinal plant materials. Latest research into quality control, Akyar I (Ed.), InTech, 67-81.

3. D'Aoust, J. Y. 1994. Salmonella and the international food trade. International Journal of Food Microbiology, 24(1-2), 11-31.

4. Farag, S. A.; Abd, E. M. and Ahmed, G. B. 2014. Antioxidant Enhancement of Some Arabic Date Varieties by Using Gamma Irradiation in Reference to Microbial Infection During Storage. Isotope and Radiation Research, 46(2), 205-220.

5. Farag, S. E. A. ; Shaltoot, A., Emam, M. ; El Nawawey, M. and Ezz El Dien,A. 2013. Physicochemical-microbiological studies on irradiated date fruits with studying migration monomers of packages materials. J. Microb. Biochem. Technol., 5:(1),6-12.

6. Farkas, j. 1988. Irradiation of dry food ingredients . CRC Press ,Inc.,Florida. 
7. Farkas, J. 1998. Irradiation as a method for decontamination food. Int. J. Food Microbiol., 44:189-204.

8. Fowles, J.; Mitchell, J. and McGrath, H. 2001. Assessment of cancer risk from ethylene oxide residues in spices imported into New Zealand. Food and Chemical Toxicology, 39(11): 1055-1062.

9. Goupy, P.; Hugues, M.; Boivin, P. and Amiot, M. J. 1999. Antioxidant composition and activity of barley (Hordeum vulgare) and malt extracts and of isolated phenolic compounds. Journal of the Science of Food and Agriculture, 79(12): 1625-1634.

10. Horváthová, M. S. J. 2007. Changes in antioxidant activity induced by irradiation of clove (Syzygium aromaticum) and ginger (Zingiber officinale). Journal of Food and Nutrition Research, 46(3):112-122.

11. Hossain, M. A.; Shah, M. D.; Sang, S. V. and Sakari, M. 2012. Chemical composition and antibacterial properties of the essential oils and crude extracts of Merremia borneensis. Journal of King Saud University-Science, 24(3): 243-249.

12. Ichinoe Zirnstein, G. W. and Rehberger, T. G. 1983. Microbiol. Rev. in central Montana. International Symposium on Biological Control, 51: 221- 227.

13. Ji, J. L.; Huang, X. F. and Zhu, H. L. 2012. Curcumin and its formulations: potential anti-cancer agents. Anti-Cancer Agents in Medicinal Chemistry, 12(3), 210-218.

14. Lee, J. H. ; Sung, T. H. ; Lee, K. T. and Kim, M. R. 2005. Effect of gammairradiation on colour, pungency and volatiles of Korean red pepper powder. J. Food Sci., 69 (8): 585-592.

15. Lee, S. Y. 2004. Irradiation as a method for decontaminating food. Journal of Food Safety, 3, 32-35.

16. Liju, V. B.; Jeena, K. and Kuttan, R. 2012. Acute and subchronic toxicity as well as mutagenic evaluation of essential oil from turmeric (Curcuma longa $\mathrm{L}$ ). Food and Chemical Toxicology, 53:52-61.

17. Little, C. L.; Omotoye, R.,Mitchell, R. T. 2003. The microbiological quality of ready-to-eat foods with added spices. International journal of environmental health research, 13(1), 31-42.

18. Miller, H. E.; Rigelhof, F.; Marquart, L.; Prakash, A. and Kanter, M. 2000. Wholegrain products and antioxidants. Cereal foods world, 45(2): 59-63. 
19. Mohankumar, S. and Farlane, J. R. 2011. An aqueous extract of Curcuma longa (turmeric) rhizomes stimulates insulin release and mimics insulin action on tissues involved in glucose homeostasis in vitro. Phytotherapy Research, 25 (3): 396-401.

20. Naguib, A.E.M.M.; El-Baz, F. K.; Salama, Z. A.; Hanaa, H. A. E. B.; Ali, H. F. and Gaafar, A. A. 2012. Enhancement of phenolics, flavonoids and glucosinolates of Broccoli (Brassica olaracea, var. Italica) as antioxidants in response to organic and bio-organic fertilizers. Journal of the Saudi Society of Agricultural Sciences, 11(2): 135-142.

21. Niamsa, N. and Sittiwet, C. 2009. Antimicrobial activity of Curcuma longa aqueous extract. J. of Pharmacology and Toxicology, 4(4):173-177.

22. Parveen, S.; Das, S.; Begum, A.; Sultana, N.; Hoque, M. M. and Ahmad, I. 2014. Microbiological quality assessment of three selected spices in Bangladesh. International Food Research Journal, 21(4): 1327-1330.

23. Pundir, R. K. and Jain, P. 2010. Comparative studies on the antimicrobial activity of black pepper (Piper nigrum) and turmeric (Curcuma longa) extracts. International Journal of Applied Biology and Pharmaceutical Technology,: I: (2): 0976-4550.

24. Shiyou, Li. ; Wei, Y. ; Guangrui, D. ; Ping, W. ; Peiying, Y. and Bharat, B. A. 2011. Chemical composition and product quality control of turmeric (Curcuma longa L.). Pharmaceutical Crops, 2: 35-39.

25. Singleton, V. L. and Rossi, J. A. 1965. Colorimetry of total phenolics with phosphomolybdic- phosphotungstic acid reagents. Am. J. Enol. Vitic., 16:144158.

26. Swain, T. and Hillis, W. E. 1959. The phenolic constituents of Prunus domestica 1 -The quantitative analysis of phenolic constituents. J. Sci. Food Agric., 10: 6368.

27. Wang, Y.; Zhaoxin, Lu.; Fengxia, L.V. and Xiaomei, B. 2009. Study on microencapsulation of curcumin pigments by spray drying. Eur. Food Res. Technol., 229:391-396.

28. Zaied, S. E. A.; Aziz, N. H. and Ali, A. M. 1996. Comparing effects of washing, thermal treatments and gamma irradiation on quality of spieces. Molecular Nutrition \& Food Research, 40(1):32-36. 


\title{
تأثثير التثعيع والمعاملات الحرارية على مضادات الاكسدة والحمل الميكروبى للكركم
}

\author{
جادو بكر أحمد جادو \\ معهُ بحوث تكنولوجيا الاغذية - مركز البحوث الزراعية بالجيزة - وزارة الزراعة - مصر
}

يستخدم الكركم وهو الاسم الثنائع للريزوم لنبات Curcuma longa L. في عديد من الاستخدامات

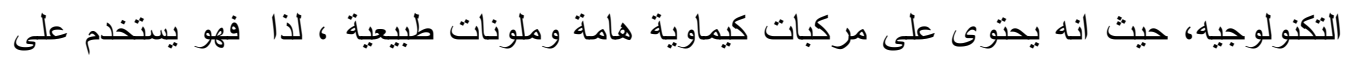

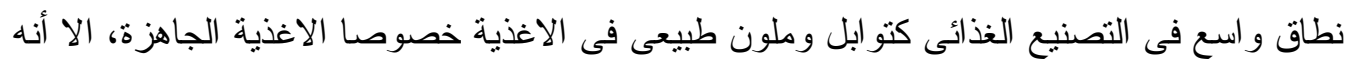

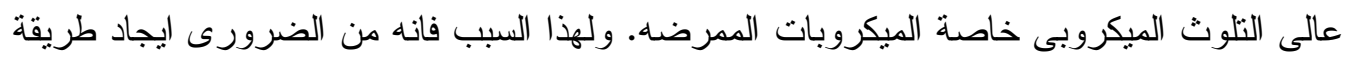
لتعقيم الكركم من غير ناثير على جودته وقد تم تتفيذ العمل الحالى لدراسة مقارنة باستخدام طرق وله طبيعية مثل الحر ارة المنخفضة (" 0.0

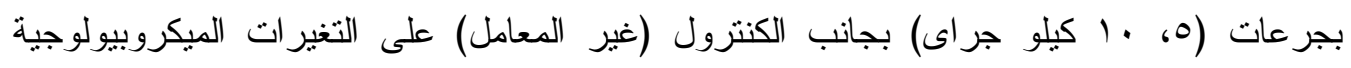

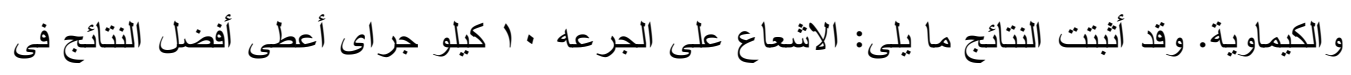

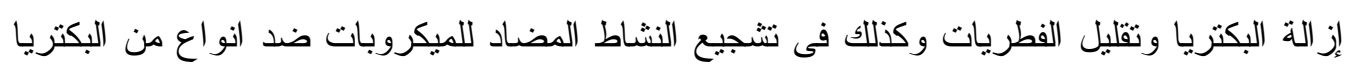

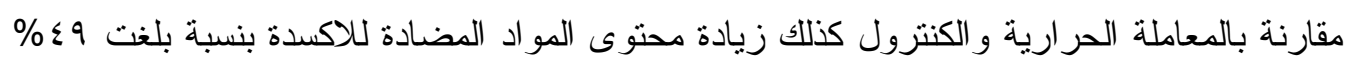

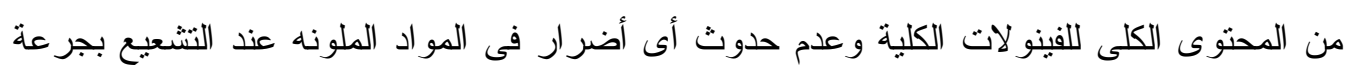

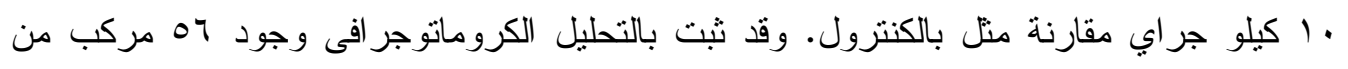
الفينو لات و الفلافونيدات حيث تكسرت المركبات الكبيرة و اعطت مركبات فينولية عديدة أكثر فاعلية و هو ما يعطى التوصية باستخدام الجرعة ـ ـ كيلو جراى للحفاظ على جودة الكركم مع تقليل الحمل الميكروبى. 